\title{
Stockholm Syndrome: Radical Islam and the European Response
}

\author{
Alex Schulman \\ Published online: 30 January 2009 \\ (C) The Author(s) 2009. This article is published with open access at Springerlink.com
}

\begin{abstract}
This paper argues that too restrictive an understanding has governed both academic and popular analysis of the social, cultural, and political conflicts between the Western European majorities and their Islamic minorities. These conflicts are typically viewed through the prisms of majority racism and/or minority economic disadvantage. While such social facts are undoubtedly important, I argue that the ideology of radical Islamism must be taken seriously in any analysis of the problem. Thus, I do two things in this essay. I outline the elements in twentieth-century radical Islamic writings that relate to the relationship between (broadly understood) Islamic and Western civilization; I also offer an overview of the now long-lived situation of culture war in Western Europe that supports my argument that Islamic cultural pathology, more than European racism, is the chief causal factor. This is intended as a warning that "clash of civilization" and "Islamo-fascism" models, usually disparaged in the academy, must be taken quite seriously.
\end{abstract}

Keywords Radical Islam $\cdot$ Europe $\cdot$ Secularism $\cdot$ Clash of civilizations

Even the Western world realizes that Western civilization is unable to present any healthy values for the guidance of mankind. It knows that it does not possess anything which will satisfy its own conscience and justify its existence....We will be extremely outspoken with them: 'The ignorance in which you are living makes you impure, and God wants to purify you; the customs which you follow are defiling, and God wants to cleanse you'...you will look upon the life you are now living with disgust.

Sayyid Qutb, Milestones

\footnotetext{
A. Schulman $(\bowtie)$

1908 Warfield Ave. \#2, Redondo Beach, CA 90278, USA

e-mail: alex19@ucla.edu
} 
Despite the stereotype of a rational, post-Christian Europe looking ruefully across the Atlantic at its Bible-thumping progeny, Western Europe's troubles with theocratic irredentism are more serious than those of the USA, albeit in different ways. Whether European Christianity is in fact in its terminal stages or not, the influx of Muslims from North Africa, the Middle East, and South Asia means that the kulturkampf over religion and the state that many had thought decided in the times of Bismarck and the troisième republique has returned with a vengeance and returned in the guise of a theocentric culture that, before a distance into Europe's expansionist period, had often presented itself as an annihilatory threat. The ghetto-ization and nonassimilation of European Muslims, coupled with their comparatively high birth rates and the wave of terrorism and urban crime that afflicted Western European cities in the 1990s and 2000s, has led some commentators - and not only ultra-right ones - to sound veritably Spenglerian alarms of cultural suicide and collapse.

Such Spenglerism is certainly too extreme; also fundamentally misguided is the opposing left-liberal viewpoint that only European racism accounts for the cultural pathologies of European Muslims, without which coexistence would be peaceful and easy. Three synchronous and interacting trends must also be held responsible for this bleak outcome. One was the vast influx of liquidity into the Gulf monarchies starting with the oil price hikes of the 1970s, some of which were recycled into Saudifinanced and Wahabbist-oriented mosques and schools throughout the world, including in Western Europe. Second was the immigration policies of the European states, which, for too long, stressed communalism at the expense of assimilation and acculturation - partially due to maintenance of the fiction that the immigrants were "guest workers" who would eventually return home, partially due to the ascendancy of Multiculturalism as a political ideology. Such immigration policies also had the perverse effect of importing rural and conservative Muslims in greater numbers than urban, secular ones; of institutionalizing ghetto-ization through "family reunification" policies that left no need for intermarriage; and of allowing the most radical and anti-Western imams into Europe on the basis of spurious claims to political asylum. ${ }^{1}$ Third was the general post-1968 ideological climate of bien-pensant, antianti-communist Europe, which stressed Western post-colonial guilt, denounced the behavior of European settler colonies like Israel and South Africa over and above other regimes of equal or greater criminality, and broadly saw the Third World "wretched of the earth" take the place of the industrial proletariat as the object of revolutionary fantasy. Thus, non-Western misbehavior or cultural pathology has been too easily viewed through the Marxist lens of material deprivation-that is, when it is not simply embraced as an exotic spot of color enlivening the drab backdrop of "one-dimensional" Western societies. "The memory of the role played by Islam in anti-colonial struggles is revived and acted out again, prompting its transformation into a kind of cultural resistance the hegemony of the West" (Taguieff 2004, p. 52).

\footnotetext{
${ }^{1}$ Philip Jenkins goes so far as to say that "Multiculturalism makes it much easier to practice Islamic fundamentalism in Europe than in most Muslims lands" (Jenkins 2007, pp. 186-187) (http://www. archbishopofcanterbury.org/1575)

${ }^{2}$ This tendency is dissected well by French philosopher Pascal Bruckner in works like (Bruckner 1983, 2006). (http://www.telegraph.co.uk/news/uknews/1574695/Extremism-flourished-as-UK-lost-Christianity. html)
} 
Academe in the West, with rare exceptions, has yet to look this process squarely in the face. The statistics concerning Muslims in Europe are unpleasant and give every indication not only that assimilation has not occurred but also that a radicalization (perhaps one could call it lumpen-Islamization) has occurred that has in some ways left Europe a more fertile ground for radical Islam than what exists in many Muslim countries.

\section{Ordinary Jihadism}

British polling after the terrorist attacks of July 7, 2005 revealed that $26 \%$ of Muslims identified no loyalty at all to Britain, $40 \%$ supported the imposition of Sharia law there, 13\% said Al Qaeda-like attacks on British soldiers and citizens were justified (this jumped to $40 \%$ when the question was whether British Jews were legitimate targets) and that Mohammed Sidique Khan and his coconspirators were "martyrs," and 47\% supported suicide attacks in Israel proper. Such results were replicated, more or less, in other nations. A Pew survey found that around 15\% of Muslims in France, Spain, and Britain said that violence against civilians would be justified "in name of Islam," a level comparable to Pakistan's, and that only $17 \%$ of British Muslims believed that Muslims carried out the 9/11 attacks (also equivalent to Pakistani numbers). A poll in Germany revealed that nearly a third of German Muslims believed that Islam must become the state religion in every country, a third agreed that violence could be legitimately used against non-believers if it served Islam, and 56\% said that Muslims should not adapt to Western ways of life but should be able "to live according to Islam." A post-9/11 survey of Moroccan immigrants in Holland showed that 21\% stood in support of a Muslim holy war against Americans. Over half of British Muslims supported boycotting Holocaust Memorial Day while agreeing that British Jews had "too much power," and barely half agreed that Israel has a right to exist; $58 \%$ of British Muslims agreed with the statement that despite the right of free speech, anyone who "insults Islam" should face criminal prosecution; a Guardian poll found that only one third of British Muslims claimed they wanted more integration into mainstream society (Laqueur 2007, pp.72, 82; Jenkins 2007, 24, 163-168, 242, 251; Shore 2006, pp. 5, 20; Bawer 2006, p. 166).

Coexistent with such attitudes has been the emergence of an urban underclass of young Muslim males spurring Western European crime rates once thought to be the exclusive fruits of American exceptionalism. Europe's crime rates have converged with and even overtaken America's in many areas-Britain's assault rate is now worse than that of the USA, while Norway's, Holland's, and Sweden's have caught up. In terms of theft, the USA is now safer on average than Britain, Denmark, France, Germany, or Norway; one is now around five times as likely to be robbed in Copenhagen as in New York City. Between $70 \%$ and $80 \%$ of reported violent crime in Oslo is committed by Muslims (Laqueur 2007, 46-47; Wikan 2002, p. 53). ${ }^{3}$ By the mid-2000s, Sweden had a per capita murder rate twice that of the USA. In

\footnotetext{
${ }^{3}$ The latter author points out that statistics are typically unreliable because, largely for political correctness reasons, Norway and other European states do not allow reporting of the ethnic background of those who commit crimes (p. 43). But there is also reason to think that much violence or threats of violence committed by Muslims against other Muslims goes unreported due to fear of physical reprisal, fear of shunning, and omertà culture. (http://www.timesonline.co.uk/tol/news/world/europe/article3419706.ece)
} 
Malmö, now nearly half ethnically non-Swedish, the incidence of rape was six times higher than in neighboring Copenhagen, child rapes had doubled in a decade, and robberies had increased $50 \%$ in the autumn of 2004 alone. The following May Sweden's government released a report blaming the spiking crime rate on Swedish racism, which it defined as the tendency to see integration in terms of "two hierarchically ordered categories, a 'we' who shall integrate and a 'they' who shall be integrated." When University of Oslo Professor Unni Wikan reported a few days before $9 / 11$ that $65 \%$ of rapes in Norway were committed by Muslim men, she saw fit to add that "Norwegian women must take their share of responsibility for these rapes" because Muslim men found Western dress too provocative to stand: "Norwegian women must realize that we live in a multicultural society and adapt to it" (Bawer 2006, pp. 55, 205).

That a scholar of Wikan's intellectual fortitude would make such a remark is certainly a sign of the cultural defeatism that has spread through Western Europe's political elite- - for Wikan is no unreflective diversity booster and indeed has written incisively for years on the way in which the European welfare bureaucracies have crippled their immigrant communities. She has often been unsparing in her critique of the Multiculturalist viewpoint, writing that "the antiracist banner has forced the authorities to seek cover where they hid in the hope that problems would go away or sort themselves out," that banner unfurled in "a policy of welfare colonialism that undermined people's capacity for selfhelp." She mourns politicians who "talked as if antiracism, nondiscrimination, and respect for 'their culture' would do the trick of integrating immigrants into Norwegian society." And she complains that the Norwegian social work bureaucracy's ethos has "often come to mean authorization to mistreat female children - those of immigrants. For that was the effect, if not the intention, of much social work. To my mind, the explanation lies with the peculiar conjunction of antiracism and Orientalism that has plagued Scandinavian immigration policies" (Wikan 2002, pp. 6-7, 64, 209). ${ }^{4}$ Wikan provides a single-country case study of continent-wide social trends:

What did the study show? An unemployment rate of 52 percent for refugees who had been in the country for five years or more. But even those who were working could not support themselves in most cases: 90 percent of all refugees in Trondheim received some form of social welfare, with dramatic effects on the city budget. Constituting only 1 percent of the population at the time, refugees consumed 27 percent of its social welfare benefits...[the] unemployment rate among refugees in Oslo was 60 percent in 1995, even higher than the 52 percent found in the Trondheim study five years earlier that forced the director of immigration to resign.... Whereas non-Western immigrants make up 13 percent of Oslo's population, they consume 37 percent of the social welfare

\footnotetext{
${ }^{4}$ As she explains further, "Ask any principal, teacher, or social worker (as I have), and they will be able to report how they, or others they know, have been subject to verbal and physical assault by immigrants, usually men, who claim their rights as being violated.... 'Racist' has become a 'deadly word'...it pierces the heart of the well-meaning Scandinavian, whose cherished identity is that of world champion of all that is kind and good... But there is a price to be paid for such high morality, and it is paid neither by those who pride themselves on supreme tolerance toward immigrants, professed as 'respect for their culture,' nor by those who claim 'racist' to claim or enforce such respect." Wikan (2002). p. 25 (http://news.bbc.co.uk/1/ hi/education/7204635.stm)
} 
budget... Whereas only 4 percent of native Norwegian children lived in families where neither the father nor the mother was employed or undergoing education, 50 percent of refugee children did (Wikan 2002, pp. 43, 46-47).

In contrast to her somewhat cavalier response to the rape of white Europeans cited above, Wikan's book is replete with poignant stories of the violence done to women within Norway's Islamic underclass. Here, recounting that "in a six-month period, at least five young women of Middle Eastern background were murderously attacked in Sweden by their kinsmen," the author stiffens up: "she was slaughtered in cold blood for wanting to be - simply — a girl in a civilized nation (Wikan (2002). p. 93)." Only relatively recently has the Western European press and social services apparatus begun to look into the true extent of honor killings, forced marriages, and routine gang raping that occurs inside Europe's Muslim communities. Indeed, there is considerable evidence that in many Western European cities, rape has become a grotesque rite of passage for Muslim youth gangs, and while this burden falls most heavily on the Muslim girls in their neighborhoods, improperly dressed (i.e., non-veiled) European women are often considered legitimate targets as well (Laqueur 2007, pp. 76-77; Jenkins 2007, p. 185) [also see Bellil's (2002) account]. This is just one of the areas where lumpen-Islamization and European social decay must be seen as interrelated and in ways that have little to do with conventional explanations like white racism. There are good reasons to see the problems of Muslim communities in Europe as a result of cultural pathologies rather than racism. This is not to say that xenophobia does not exist or plays no part in Europe's nonintegration crisis. But if prejudice is to account for the often dismal statistics concerning European Muslims (hugely disproportionate rates of criminality and incarceration, disproportionately high rates of welfare dependency, low levels of educational attainment, etc.), why do we not see the same pattern in non-Muslim non-white communities $?^{5}$ Only $3 \%$ of Turkish immigrants in Germany make it to college - and yet, Indian and East Asian students actually score better than whites do across Western Europe. British Muslims are three times as likely to be jobless as British Hindus, and Muslims in Britain have also sat out the notable rise in educational attainment among Hindus, East Asians, and Caribbean blacks, either stagnating or (as with the Bangladeshi community specifically) declining (Laqueur 2007, pp. 43-44; Shore 2006, p. 107).

While the professoriate weighed the pros and cons of French girls donning the hijab at school, ${ }^{6}$ wondering whether it signified oppression or liberation or maybe a bit of both, cultural pathologies more obviously destructive of liberal democracy

\footnotetext{
${ }^{5}$ Wikan points out that Norwegian Tamils show an almost one hundred percent labor force participation in some areas; but, "In Denmark in 1995, 35 percent of non-Western immigrants were unemployed, compared to 4.5 percent of native Danes... In the Netherlands in 1995, 41 percent of Turks and 27 percent of Moroccans were registered as unemployed as against 6 percent of the Dutch" (Wikan 2002, pp. 48-49). Comparing such numbers to those of the U.S., where labor force participation is equal between immigrants and natives, should lead one to pause at the next lurid contrast between the "savage" laissezfaire of the Americans and Europe's kinder, more nurturing welfare states. (http://www.timesonline.co.uk/ tol/news/world/europe/article3419706.ece)

${ }^{6}$ See, for example, Klausen (2005), chap. 6, which despite being called "Sexual Politics and Multiculturalism," focuses almost exclusively on the headscarf controversy. (http://www.iht.com/articles/ 2008/01/20/business/libel21.php)
} 
proliferated. It is possible that they had "nothing to do with Islam" (that faithful rejoinder, sure to be heard if one flips through the cable news after any terrorist attack) and simply represented the growing pains of rural, tribal communities adjusting to post-industrial wealth and opportunity. But again, as with the rejoinder to Islamist terrorism, the argument strains credulity, if only because such atrocities are so often carried out in Islam's name, and so rarely in those of the other minority groups in the West. $^{7}$ This of course is no comment on the day-to-day personal behavior of the majority of European Muslims, which may well be beyond reproach or at least average. But the sad fact is that in an atmosphere of radicalization among religious authorities and successful community intimidation, such decency may be less important than one wishes.

Indeed, European states have only recently started to roll back the Multiculturalist policies that have perversely served to strengthen the hand of the most irredentist and anti-Western Muslim authorities: particularly foreign-born and Saudi-funded imams, many of whom were kicked out of notoriously anti-Muslim places like Jordan and Algeria for being too radical (thus earning "asylum" in Europe) and many of whom preach exclusively in Turkish, Arabic, or Urdu. "Of the many hundred of imams," Walter Laqueur writes of a study in France, "only 4 percent had French nationality, many of the others did not know French or had imperfect command of the language, and dozens saw their main assignment as open incitement against the authority (Laqueur 2007, p. 53)." In his critique of Multiculturalism, Brian Barry predicted that, "if the state is going to lend its coercive powers to attempts to maintain the cultural distinctiveness of groups, it is hard to imagine how this can be done in any way that does not strengthen the hands of those within each group who wish to impose on its members uniform beliefs and standards of conduct" (Barry 2002, p. 129). So it has proven. Unni Wikan admits of European Multiculturalism that "the concept of 'culture' at the base of these policies was hollow: it rested on the assumption that to each culture there is a single people that speaks with a common voice...oppression and power abuse, were absent from this rosy notion... any spokesman could speak on behalf of 'the culture'; and many did (Wikan 2002, p. 63)." As Bruce Bawer puts it, "European Muslims suffer less from politicians' prejudice than from politicians' accommodation and appeasement of the prejudices of tyrants within Muslims communities." The "see-no-evil attitude toward the autocrats who run the Muslim community makes them, in effect, the enemies of those within that community who despise the autocrats' tyranny and wish to live as free, equal citizens of a Western democracy" (Bawer 2006, pp. 52, 65).

A glaring example is that of Omar Bakri Mohammed, who sought and received asylum in Great Britain, eventually setting up a radical splinter group of the already radical Hizb-ut-Tahir and operating in the same Islamist circles radiating around the infamous Finsbury Park mosque. Hizb-ut-Tahir shared Bin Laden's goal of restoring

\footnotetext{
${ }^{7}$ As just one example, it is often pointed out that Al Qaeda terrorist attacks in the West follow upon Bin Laden's horror at the stationing of non-Muslim troops in Saudi Arabia and Iraq. Then, should we not wonder why the long-term stationing of US soldiers off of Cuba does not lead to the formation of a transnational Latin American terrorist army? Or why America's bloody misadventures in Southeast Asia have not led to a single Buddhist cell group attacking Los Angeles (or planning to, as far as I know)? (http:// www.dailytimes.com.pk/default.asp?page $=2008 \% 5$ C06\%5C08\%5Cstory_8-6-2008_pg7_14)
} 
the Islamic Caliphate. Although banned throughout most of the Muslim world, the group surfaced in London in the 1990s, holding a national conference and rally in Trafalgar Square and recruiting at universities. In Denmark, they have passed out leaflets advising Muslims to kill Jews wherever and whenever possible. During the first Gulf War, Bakri said that Prime Minister John Major could be legitimately assassinated if he traveled to Saudi Arabia; in 1995, he called for Queen Elizabeth's conversion and threatened that Muslims would not rest until "the black flag of Islam flies over Downing Street"; he supported Al Qaeda's 1998 embassy bombings in Africa and, more recently, the bombings in Madrid and London and specifically cited the Beslan schoolhouse massacre as the type of attack it would be legitimate for British Muslims to carry out; he has called for stoning homosexuals, adulterers, and fornicators to death and abolishing public mixing between the sexes. When an organization, called the "Sharia Court of the UK," issued its fatwa against Terence McNally (for his play Corpus Christi), Bakri announced that McNally could only have the death sentence lifted through conversion. In 1996, it was revealed that Bakri had received dole, child benefits, income support, a disability allowance, and housing benefits - an impressive record of largesse from a society he claimed to detest. The public was briefly outraged. But front groups set up by Bakri's organization continued to receive tax benefits from the British government, until it was shown in 1999 that one of them, the "Muslim Cultural Society," was still churning out fatwas against McNally and Salman Rushdie (Wiktorowicz 2005, pp. 9, 64, 124, 144; Jenkins 2007, pp. 216-218; Bawer 2006, pp. 25, 145, 180).

Or consider Khalil el-Moumni, a Rotterdam Imam expelled from Morocco for his radicalism. In 1998, he said that "Western Civilization is a civilization without morals. In the Netherlands it's permitted for homosexuals to marry each other. The Europeans stand lower than dogs and pigs" and justified physical attacks against gays. Or the Spanish imam who told his flock that "our duty is to prepare the men of Islam to fight the spirit of homosexuality that is rising in the West," though why any struggle would be necessary is unclear given that "history teaches us that societies where men have lost their courage and their virility and women govern and walk undressed on the streets, who encourage decreasing birth-rates, sterilizing men and women, end up disappearing. Muslims must struggle with any means whatsoever and must not let themselves be subjugated by pagan Europe." Or another Moroccan export, Mohammed Fizazi, Imam at Hamburg's Al Quds mosque, a base of operations for the planning of 9/11: In early 2001, he advocated killing all Christians and Jews "no matter if it's a man, woman or a child" and was later linked to terrorist attacks in Madrid and Casablanca. Or Sheik Yusuf al-Qaradawi, "a respected voice among European Muslims" who "claimed that female rape victims should be punished if they were dressed immodestly when they were raped (Jenkins 2007, pp. 185, 188, 220-221)." Or Denmark's Sheikh Abu Laban, rarely mentioned in the furor over the Jyllands Posten cartoons: "Few outside of Denmark realized that the cartoon of Mohammed wearing a turban with a bomb inside bore the likeness of Sheikh Abu Laban, one of Copenhagen's more radical Muslim clerics. A political refugee in Denmark since 1984, Abu Laban has called for the return of the caliphate in Arab lands and suggests that eventually enough converts could exist to bring Europe under the caliphate as well" (Shore 2006, p. 73). Or another Copenhagen cleric who said in 2004, "No Muslim can accept secularism, freedom, and 
democracy. It is for Allah alone to legislate how society shall be regulated! Muslims wish and long for Allah's law to replace the law of man." Or Abu Abdullah of London's Finsbury Park mosque, who in 2005 called non-Muslims "filthy" and urged jihad upon British Muslims, adding that if they could not make it to Iraq, "this is our front line here." Or the Oslo imam who claimed that since Islam mandated the payment of jizya, or protection tax, from Christians to Muslims, Muslims in Norway had the right to steal from natives. Or Danish mufti Shahid Mehdi, who said that women and girls (including non-Muslims) who did not wear headscarves were to be held responsible if they were raped (Bawer 2006, pp. 16, 26, 185).

One of the more astounding cases is that of Mullah Krekar, né Faraj Ahman Najmuddin, the Iraqi-Kurdish guerilla leader and founder of Ansar-al-Islam, an organization that imposed Taliban-like rule on northern Iraqi areas between 2001 and the 2003 American invasion. Krekar entered Norway as a refugee in 1991 and founded "Islamic Vision," a radical Muslim organization that received the equivalent of $\$ 35,000$ in government support. Eventually Krekar-despite receiving the public support of groups like SOS Racism and the Anti-Racism Center-became too much for the famously conflict-averse Scandinavians, but both Norway and The Netherlands refused to extradite Krekar to Jordan for fear of the treatment he would receive there. What is more, in August 2003, a Dutch court awarded Krekar 4,970 euros in compensation for having been imprisoned in transit in Holland; the next year, an appellate court bumped up the payment to 45,000 euros (Bawer 2006. pp. 60-64).

Perhaps, these are the anomalous extremes? Certainly, most European imams do not go so far as to openly incite rebellion, but the wide availability of such anecdotal examples signals a more basic problem among the "moderates," that is, a stalwart refusal to lead European Muslims in the direction of embracing Western liberal norms. Even the mainstream organizations that have claimed communal sanction to speak for European Islam, though adept at doing damage control after bombings, have a general record that is spotty at best. The former leader of the Muslim Council of Britain (MCB) Iqbal Sacranie compared the leaders of Hamas to Mahatma Gandhi and Nelson Mandela and declared after Ayatollah Khomeini's fatwa that death was too kind a punishment for Salman Rushdie: He later became an adviser to Tony Blair and was knighted. The Secretary of the Bradford Council of Mosques went even further during the Rushdie affair: "Muslims here would kill him, and I would willingly sacrifice my own life and that of my children to carry out the ayatollah's wishes should the opportunity arise." During a mid-2000s flare-up concerning honor killings among European citizens - over just a 6-month period in 2004-2005, 11 women were victims in The Hague alone, and British authorities revealed that they were reinvestigating 117 suspicious deaths or disappearances as potential kin murders - an MCB spokesman said of one accused father, "many Muslims would understand [his] being upset by his daughter's apparent rejection of her faith" and by her "growing up not with his value system but with someone else's." During a conflict over the repeal of a piece of anti-gay legislation in Britain, Dr. Hasham ElEssawy, director of Islamic Society for the Promotion of Religious Tolerance in the UK, typically seen as a moderate voice, cited the Qur'an as providing the correct punishment for lesbians: "Keep the guilty women in the homes until they die, or till God provides a way out for them." When asked about the murder of Theo van Gogh, physician Zahir Mukhtar, a longtime leader of Norway's Muslim Council, voiced his 
"understanding" of the assassin Bouyeri's actions and added that he could not accept the supremacy of Norwegian law over sharia (Laqueur 2007, p. 73; Jenkins 2007, p. 237; Bawer 2006, pp. 23-26, 197).

There is a scene in the film My Beautiful Laundrette (1985) in which an immigrant landlord, refusing a plea from a fellow South Asian for financial clemency, replies angrily, "I'm a professional businessman, not a professional Pakistani!" If we trust the argument of Wikan and others that "Professional Muslims" have hindered the assimilation of their communities, then the answer may be relatively simple: Stop working with them. ${ }^{8}$ But there is evidence that the untoward pressure also goes in the opposite direction. Consider Tariq Ramadan, probably the most celebrated intellectual symbol of Euro-Islamic dialogue, who notoriously failed to condemn the stoning of adulterous women during a televised debate with Nicholas Sarkozy - he later said that a condemnation would have made him friends in the French government but lost him "ordinary Muslims."

\section{"Islamic Bolshevism"}

Europe's radical imams are heirs to a purist, revanchist, and openly imperialistic strain of Islam that — while it certainly finds intellectual support going all the way back to the Qur'an and Hadiths - is more specifically an outgrowth of the Wahabbist movement that arose in Arabia in the eighteenth century and is now the Saudi kingdom's second most important export. Radical Islam took its more familiar form in the calls for fundamentalist renewal that followed the dismantling of the Ottoman Caliphate after World War I, and subsequent opposition to nationalist, secularizing or pro-Western regimes like those of Nasser, the Ba'ath, and the Pahlavis. That these purist movements have coincided with reactions to Western inroads into Muslim-led territories - from the Russian-Turkish wars at the end of the eighteenth century to the death throes of the last caliphate in the twentieth - has helped produce the oddity whereby a blatantly imperialistic outlook, just like its old Nasserite pan-Arab foil, continues to be seen through the lens of "anti-colonial" struggle long after such terminology has ceased to make any sense. The popularity of writers like Franz Fanon and Edward Said and their influences and epigones in the academy has legitimated a sort of historical amnesia in the West.

Islam is arguably the most successfully imperial idea structure in the history of the world. That it has continued to keep and gain adherents even in a time of cultural eclipse at the hands of westward and eastward neighbors may attest to strength, not weakness or confusion. Samuel Huntington (in)famously guessed that "the twentieth century conflict between liberal democracy and Marxism-Leninism" would prove "a fleeting and superficial historical phenomenon compared to the continuing and deeply conflictual relation between Islam and Christianity (Huntington 1996,

\footnotetext{
${ }^{8}$ An easy example: local majorities virtually never support emphasis on training in "native" languages (i.e., Turkish, Arabic, and Urdu), but some European states have allowed Muslim students to be corralled into such programs on the recommendation of Multiculturalist elites. (http://www.cphpost.dk/get/107525. html)
} 
p. 209)." It is similarly possible that Western imperialism in Asia and Africa will prove a relatively brief phenomenon when compared with Islamic imperialism in these areas and perhaps even in Europe itself. One historian writes:

For almost a thousand years, from the first Moorish landing in Spain to the second Turkish siege of Vienna, Europe was under constant threat from Islam. In the early centuries it was a double threat-not only of invasion and conquest, but also of conversion and assimilation. All but the easternmost provinces of the Islamic realm had been taken from Christian rulers, and the vast majority of the first Muslims west of Iran and Arabia were converts from Christianity. North Africa, Egypt, Syria, even Persian-ruled Iraq, had been Christian countries, in which Christianity was older and more deeply rooted than in most of Europe. Their loss was sorely felt and heightened the fear that a similar fate was in store for Europe (Lewis 1993, p. 13).

Another historian points out that "contrary to the conventional wisdom, it is the Middle East where the institution of empire not only originated (for example, Egypt, Assyria, Babylon, Iran, and so on) but where its spirit has also outlived its European counterpart," and gives a Gibbonesque account:

Within twelve years of Muhammad's death in June 632, Iran's long-reigning Sasanid Empire had been reduced to a tributary, and Egypt and Syria had been wrested from Byzantine rule. By the early eighth century, the Muslims had extended their domination over Central Asia and much of the Indian subcontinent all the way to the Chinese frontier, had laid siege to Constantinople, the capital of the Byzantines, and had overrun North Africa and Spain. Had they not been contained in northwest France by the nobleman Charles Martel at the battle of Poitiers (732) they might well have swept deep into Europe (Karsh 2006, pp. 2, 20).

Significant Western inroads into Muslim-ruled lands are a comparatively late arrival. At its earliest, this process dates from the mid-to-late-eighteenth century, the 50 or so years in which Great Britain assumed the imperial role in the Indian subcontinent, Catherine the Great entertained the possibility of retaking Constantinople and breaking up the Ottoman Empire, and Napoleon invaded Egypt. Before that, the most serious threats to the Islamic empires had come from people to the east, not the west - and even the Mongols were speedily converted. The Crusades, though now a central event in Bin Ladenism's Manichaean history, were seen by many Muslim leaders at the time as an explicable and minor Christian attempt to regain Muslim-conquered territory. Philip Jenkins sees a basic defect in popular historical understanding:

In Euro-American popular history, the encounter is generally framed in terms of the Crusades, and a version of these events in which Christians are unabashed aggressors against thoroughly civilized Muslims... Yet the picture of incessant European aggression is misleading, not least because it neglects the issue of how Muslims came to establish themselves in the first place in the Near East, in Palestine, Syria, or Spain. From the seventh century through the seventeenth, Islam expanded into the Mediterranean world through military conquest and a series of 
bloody wars in which Muslims generally held the upper hand. If Europeans held a common image of Muslims as massacring and enslaving infidel populations, that picture had a solid basis in historical fact. The stories that we regard as the tragedies of interfaith intolerance, the Crusades and the Spanish Reconquista, are the two great - and rather isolated-examples in which Christian forces won major military victories (Jenkins 2007, pp. 104-105).

This is not to say that the fundamentalist (Al-Banna, Qutb, Maududi et al., culminating in the Iranian revolution) or socialist-nationalist (Nasser, the Ba'ath, Algeria's FLN) movements ${ }^{9}$ that stirred the Muslim intellectual world in the twentieth century were not spurred on by Western power and influence. But such ideologies having passed and continuing to pass under the rubric of anti-imperialism and anti-colonialism is no more plausible than similar claims made by expansionist communist powers in the twentieth century.

The ideology designed by thinkers like Sayyid Qutb with the purpose of overthrowing Westernizing leaders within the Muslim world (Qutb died in prison after Nasser cracked down on the Muslim Brotherhood) is now preached in the heart of Europe, arguably with as much success as, or even greater success than, in its intended zone. It is hard to avoid the impression that many radical imams see Paris and London as equivalents to Chechnya, Kashmir, and Baghdad as foci of global jihad. Despite Islamism's habit of denouncing corrosive Western influences, characterizations of this family of movements as "Islamo-fascism" (Christopher Hitchens, Paul Berman) or "Islamic Bolshevism" (Niall Ferguson) have some validity (Hitchens 2001; Berman 2003; Ferguson 2004). Just as the founders of the Ba'ath Party tried to Arabize blood-and-soil German fascism, Qutb sought to Islamicize the Leninist plan "that there should be a vanguard which sets out with... determination and then keeps walking on the path, marching through the vast ocean of Jahiliyyah [ignorance of divine guidance] which has encompassed the entire world. During its course, it should keep itself somewhat aloof from this allencompassing Jahiliyyah and should also keep some ties with it" (Qutb 1980, p. 12). The disciplined vanguard party within Islam mirrors the service Islam more broadly is supposed to provide the world: "a community that was to lead humanity, achieve the purposes of God on earth, and rescue humanity from the suffering it had endured at the hands of misguided leaders, methodologies and concepts," a group of believers "entrusted with the leadership of humanity in a manner never known to mankind before" (Qutb 2006, p. 2). Maulana Maududi claimed to have been strongly influenced by Alexis Carrel, a philosopher-propagandist for Vichy France, and impressed by European totalitarian movements generally (Ruthven 2002, pp. 68-

\footnotetext{
${ }^{9}$ The extent to which A is religious and B secular is questionable and certainly can be overstated in common parlance. Gilles Kepel observes that "nowhere in the Muslim world of the late 1960s did religion vanish from popular culture, social life, or day-to-day politics. Islam was merely handled in different ways by different regimes, and was combined with nationalism in ways that varied according to the social class of those who had seized power at the moment of independence" (Kepel 2002, p. 47); Efraim Karsh argues that "For all its professed secularism...pan-Arabism has not only been forced to claim allegiance to the religious belief and traditions to which most Arabs remain attached to date, but has effectively been Muslim in its ethos, worldview, and imperialist vision" (Karsh 2006, p. 133) (http://www2.ohchr.org/ english/bodies/hrcouncil/docs/7session/A-HRC-7-L11-Add1.doc)
} 
69). Maududi founded the radical Shiite Jamaat-e-Islami party in 1941 on avowedly Leninist lines, while Ali Shariati, a major intellectual influence behind the Iranian revolution, had studied in Paris and had been influenced by Fanon, Sartre, and Che Guevara: The latter wrote pamphlets entitled Red Shi'ism and What is to Be Done (Kepel 2002, pp. 34, 37; Buruma and Margalit 2004, pp. 122, 145) and lashed out against "capitalism armed with science and technology - a new magician bewitching humanity into new captivity amid the massive pitiless wheels of mechanism and techno-bureaucracies" (Shari'ati 1980, p. 39). Muslim Brotherhood founder Hassan Al-Banna was an avowed admirer of Hitler and Mussolini and rhapsodized violent self-sacrifice in a manner readable within the intellectual lineage of fascism: "Death is an art and the most exquisite of arts when practiced by the skillful artist...death in the path of Allah is our highest aspiration" (Karsh 2006, p. 209).

Sayyid Qutb - whose brother would later radicalize Osama Bin Laden as a teacher at university in Jeddah (Ruthven 2002, pp. 198-199) - announces that his purpose is to reintroduce the puritanical ethos of the seventh-century Islamic warriors into decadent modern societies, to "equip the soul with emotions, perceptions and experiences similar to those that accompanied the revelation of the Qur'an, that prevailed in the life of Muslims as they received it in the course of battles, war against one's own sinful tendencies and against the outer enemy" (Qutb 2006 , p. 3). For such warriors, "this struggle and its accompanying trials is the practical means for purifying the ranks of the community-after the initial purification of the individual soul — of ridding it of the idle and the hypocrites, of those of weak heart and weak character, or tricksters and deceivers" (Qutb 1967, p. 10). Though his aims are internationalist and universal (which is why Ferguson's "Islamic Bolshevism" seems the better term), Qutb's ideas bear a certain family resemblance to the fascist model of reclaiming an original purity from infectious foreign influences. Maududi, like Qutb, looks back to the Golden Age represented by the Caliphate, praising its "singleness of purpose.... The whole community knew it fully well that its sole aim was to propagate the Unity of Allah, disseminate good and eliminate the forces of evil and infidelity." It was "a united, cohesive polity. The entire community owed allegiance to a virtuous authority and held fast to one center. Here there was no social disorder whatsoever" (Maududi 1981, vol. I, p. 85). It is not difficult to see how such positions could serve as a manual for non-assimilation in the service of the gradual colonization of kaffir peoples. Qutb points out that "when a person embraced Islam during the time of the Prophet-peace be on him-he would immediately cut himself off from Jahiliyyah" and "all his relationships with Jahiliyyah would be cut off and he would be joined completely to Islam, although there would be some give-and-take with the polytheists in commercial activity and daily business; yet relationships of understanding are one thing and daily business is something else." A mental removal from unbelieving society, with allowances for the practical benefits dealing with infidels can provide, signals a "return to that pure source from which those people [i.e. the original Arabian Muslims] derived their guidance, the source which is free from any mixing or pollution." There "we must also derive our concepts of life, our principles of government, politics, economics and all other aspects of life." The practical side of coexistence should not lead to an ethos of long-term compromise: "Our mission is not to compromise with the practices of jahili society, nor can we be loyal to it. Jahili 
society, because of its jahili characteristics, is not worthy to be compromised with" (Qutb 1980, pp. 19-21). ${ }^{10}$

One reason that long-term coexistence with non-Muslim society is impossible on Qutb's terms is that the privatization of religion is itself a "jahili" perversion. "History has shown that Islam is unique in its ability to provide guidance for the entire range of human activity." Thus, Islamism "does not separate spiritual and secular life, for what seems to belong to the citizen and to Caesar is in reality God's property." Proper religiosity "is comprehensive and covers all aspects of life just as capillaries and nerves direct themselves to all parts of the body" (Qutb 1977, p. 3). Organic metaphors proliferate: "Islam.... is intended to penetrate into the veins and arteries of a vital society and to be a concrete organized movement." Islam is not "merely a belief, so that it is enough merely to preach it." It is "a way of life" that "takes practical steps to organize a movement for freeing man. Other societies do not give it any opportunity to organize its followers according to its own method, and hence it is the duty of Islam to annihilate all such systems, as they are obstacles in the way of universal freedom." One equally must not abide "a society in which God's existence is not denied, but His domain is restricted to the heavens and His rule on earth is suspended," i.e., a standard modern society that separates church and state. To believe the latter represents progress is misguided: "The Islamic society is, by its very nature, the only civilized society, and the jahili societies, in all their various forms, are backward societies," such that "a slight influence" from "Western sources" will "pollute the clear spring of Islam." Thus, the Muslim citizen ultimately "cannot accept any mixing with Jahiliyyah, either in its concept or in the modes of living which are derived from this concept. Either Islam will remain, or Jahiliyyah: Islam cannot accept or agree to a situation which is half-Islam and half-Jahiliyyah" (Qutb 1980, pp. 39, 75, 93-94, 116, 130).

Qutb's system ultimately promises the overthrow of all existing societies to the extent that they are non-Muslim or unwilling to grant Islam a preeminent place; but Western civilization plays a recognizably central role. Qutb's own autobiographical account cites an encounter with loose American women while studying abroad as a spur to his radicalization, and discomfort with female sexuality shows through in much of this writing. Maulana Maududi's advice to pious Muslim women implores: "purge yourselves of all the un-Islamic influences....If you find anything inconsistent with Islam, do away with it...purify the atmosphere of your homes," in particular "the outrageous elements of modernity that have crept into our homes under the British influence ought to be weeded out" (Maududi 1981, vol. I, p. 66). Fear of contamination, replete with medical analogies, is surely related to the premium placed on female virginity and chastity and the disgust with the libertarian

\footnotetext{
${ }^{10} \mathrm{He}$ expands upon this point later in the book: "A Muslim cannot go to any source other than God for guidance in matters of faith, in the concept of life, acts of worship, morals and human affairs, values and standards, principles of economics and political affairs and interpretation of historical processes. It is, therefore, his duty that he should learn all these from a Muslim whose piety and character, belief and action, are beyond reproach. However, a Muslim can go to a Muslim or to a non-Muslim to learn abstract sciences such as chemistry, physics, biology, astronomy, medicine, industry, agriculture, administration (limited to its technical aspects), technology, military arts and similar sciences and arts" (pp. 108-109). (http://www.nationalpost.com/opinion/columnists/story.html?id=5b471cb6-2b5d-44e0b5e $0-973 \mathrm{fda} 2 \mathrm{ca} 5 \mathrm{dd} \& \mathrm{p}=1$ )
} 
societies that tempt men and women away from such an ideal. Within the set of laws passed in Iran in 1981 codifying Qur'anic legal authority, more than half concerned sexual matters (Ruthven 2002, p. 123). Westernization means "moral depravity and adultery," part and parcel "of the permissive society where women freely mix with men." "The result is a society that welcomes prostitution, the female slave trade" (Qutb 1977, pp. 32, 34.), Qutb alleges. This is ironic if one defines "slavery" more generally as, say, a system in which one's life is violently controlled by unquestionable authorities, arguably the condition that prevails for many Muslim women living under de jure or de facto sexual sharia. The modern West's relatively nontraditional attitudes toward women and sexuality figure prominently in Qutb's dissection of its failures:

free sexual relationships and illegitimate children become the basis of a society, and if the relationship between man and woman is based on lust, passion and impulse, and the division of work is not based on family responsibility and natural gifts; if woman's role is merely to be attractive, sexy and flirtatious, and if woman is freed from her basic responsibility of bringing up children; and if, on her own or under social demand, she prefers to become a hostess or a stewardess in a hotel or ship or air company, thus spending her ability for material productivity rather than in the training of human beings.... Those societies which give physical ascendance to physical desires and animalistic morals cannot be considered civilized, no matter how much progress they may make in industry or science (Qutb 1980, p. 98).

Qutb elsewhere argues that "prosperity, sensual enjoyment and sexual satisfaction lead to a sinking into the morass of nervous and psychological disease, sexual perversion, constant anxiety, illness and lunacy, frequent crime, and the lack of any human dignity in life." We increasingly inhabit a world in which "mankind is wretched and is tired of bearing the burden of its materialistic civilization and luxury," in which "corruption and dissolution, nervous and mental disease, intellectual and sexual perversion are eating away the body of western civilization, destroying nations and individuals, and are forcibly opening people's eyes to evil and corruption" (Qutb 1967, pp. 25, 97). We seek instead "a stable concept of fundamentals and values" that "disciplines the progress and vital development of human life" and that "does not veer back and forth without guidance, as happened in the life of Europe when it cut loose from the moorings of belief and came to a miserable end, faintly disguised by a false glow and deceptive gleam that concealed misery, confusion, decadence, and degeneracy." An irreligious society "is always in danger of violent commotions and constant instability resulting in confused minds, anxious consciences, exhausted nerves, and pervasive corruption," which is "what befell European societies cut loose from any stable principle and now afflicts all of humanity as it strays into the wilderness in the wake of European society" (Qutb 2006, pp. 77, 87).

However implicitly or explicitly universal Qutb's promises, there are times when he cannot help but water one of the more poisonous weeds of the totalitarian outlook. A major obstacle to the re-moralization of the world through Islam remains "the tricks played by world Jewry, whose purpose is to eliminate all limitations, especially the limitations imposed by faith and religion, so that the Jews may penetrate into the body politic of the whole world and then may be free to perpetuate 
their evil designs. At the top of the list of these activities is usury, the aim of which is that all the wealth of mankind end up in the hands of Jewish financial institutions which run on interest" (Qutb 1980, p. 111). Maulana Maududi agrees and builds us the bridge between anti-Semitism and anti-Americanism. The USA "is possessed by the devil called Jewry. This dangerous group of international conspirators does not only wield economic power in the USA but also dominates the Press.... The Jews are an evil genius for the Americans" (Maududi 1981, vol. II, pp. 62-3). The Imam Khomeini alleges that it was "they who first established anti-Islamic propaganda," though "later they were joined by other groups, who were in certain respects more satanic than they." He even surmises that "the Jews (may God curse them) have meddled with the text of the Qur'an and have made certain changes in the Qur'ans they have printed in the occupied territories," in line with their "wish to establish Jewish domination throughout the world" (Khomeini 1985, pp. 27, 127). Indeed, if Jews are the collective canary in the totalitarian mineshaft, then evidence for European suffocation has been on the rise.

\section{Pogrom}

The onset of the second or Al-Aqsa intifada in Israel/Palestine meant, for Western Europe, the beginning of "a wave of Judeophobia unprecedented in scale or intensity in the post-Nazi period." The author of the previous observation notes ruefully that "not since World War II have anti-Jewish expressions had such currency in France among so many social groups, or met so little intellectual and political resistance as they have since the fall of 2000." In contrast to the hypersensitivity typically shown by Europe's establishment media toward the disparagement of immigrant groups, "Jews no longer appeared anywhere on their list of accredited victims" (Taguieff 2004, pp. 3, 7). In France alone, in 2000 alone, the reported incidence of antiSemitic attacks and threats rose exponentially, the former from nine to 116 and the latter from 60 to 603. In just the fall of 2000, synagogues were burned or firebombed at Les Ulis, Trappes, Bondy, Villepinte, Clichy-sous-Bois, Creil, Colombes, Longjumeau, Garges-lès-Gonesses, and Chevilly-la-Rue and Stains; a Jewish kindergarten in the fourth arrondissement of Paris was also put to the torch and arson committed against a Jewish nursery and primary school in Marseilles, whose main building was covered with inscriptions reading "Death to the Jews!" "Long live Bin Laden!" and "Bin Laden will conquer!" The situation remained dangerous throughout the following year:

On September 10 the president of the Drancy synagogue received a letter containing the phrases 'Death to the Jews' and 'Hell is awaiting you'; on September 11, while scenes of jubilation in Barbès (18th arondissement of Paris) greeted news of the attacks in the United States, a thirteen-year-old boy was insulted and beaten up as he left a Jewish school at Aubervilliers, and a young Jewish girl was run over by a car (which then sped off) as she left the Ozar Hatorah school at Sarcelles; on September 12, 'Long Live Bin Laden' and 'Death to the Jews' were found on the walls of the Turgot Lycée in Paris; on September 21 some fifteen second-generation North Africans shouted 'We're 
gonna kill your mother and father' at a rabbi in Villepinte; the next day two men with knives...threatened worshippers at a synagogue in the 19th arondissement of Paris; on September 27 a man put a rifle to his shoulder and made as if to open fire on the synagogue at Vitry; on October 18 pupils at a Jewish school in Saint-Ouen were chased and roughed up; and on October 24 some individuals shouted 'Death to the Jews' in front of a kosher butcher's shop in the 19th arondissement of Paris (Taguieff 2004. pp. 40-43).

This anti-Semitic wave embraced the vicious and the ludicrous. In 2002, security guards at a restaurant in the Norwegian parliament ordered a man to remove a jacket with Star of David on it, alleging that it was needlessly provocative to Muslims who might happen by and would potentially cause violence. And they may have been right in their analysis, if not their action. In 2003, a popular Jewish disc jockey in France was killed by a Muslim neighbor who slit his throat, gouged out his eyes, mutilated his face with a fork, and then reportedly announced, "I have killed my Jew. I will go to heaven." Journalist and critic Bruce Bawer, an American living in Europe throughout the second intifada, notes the same grotesque record cited above:

[S]ince 2000, anti-Semitism in France has been epidemic. Synagogues have been burned down, schools vandalized, shops attacked, rabbis beaten, children assaulted, school buses shot at, gravestones knocked over and defaced with swastikas and the name of Hitler. At Muslim demonstrations, shouts of "Death to the Jews!" have become common. On March 29, 2002, a dozen or so young men in masks smashed two stolen cars into the doors of a synagogue in Lyon and set the cars on fire. That same weekend, synagogues in Strasbourg and Marseille were burned. Shortly thereafter, Molotov cocktails were thrown at several other French synagogues. In March 2003, three men in masks carved a Star of David into the arm of a Jewish girl in Aix-en-Provence. In the spring of 2004, a rabbi's seventeenyear-old son was assaulted outside his home in a Paris suburb by attackers shouting anti-Semitic slurs. A week later, an assailant shouting "Allahu Akbar" stabbed another seventeen-year-old Jewish boy in the chest in another suburb of Paris.

Although France was the hardest hit by this long-term, low-level pogrom, much of Western Europe in fact experienced a spike in anti-Semitic incidents in the 1990s and 2000s. Synagogues were also machine-gunned or firebombed in Belgium and England (at synagogues in Swansea and Finsbury Park windows were smashed, excrement smeared on the floor and swastikas painted on the walls), while British authorities reported that, in fact, 117 Jewish cemeteries had been vandalized since 1990. Perhaps even more insidious than such splashy bouts of violence, however, has been the large-scale intimidation of Jewish students in European schools that have significant Muslim populations. In October 2003, a Swedish history professor reported that Swedish Jews could effectively no longer express their religious identity (Stars of David, yarmulkes) publicly because it ensured violence and abuse - and that authorities were advising all children and parents who complained to ignore the problem, walk away quickly, avoid confrontation, and essentially hide their religion. Public school teachers across Western Europe have reported that it is now difficult to teach history lessons about the Holocaust to Muslim pupils, such that it often has been quietly dropped from the curriculum. Some polls have since indicated that up to half of French 
Jews considered leaving the country or advised their children to do so (Bawer 2006, pp. 110, 139-151; Pryce-Jones 2006, pp. 11-14).

As difficult to accept as the wave of hatred itself, perhaps, was the long-lasting media blackout concerning it. I remember the confusion quite well. I was an undergraduate during this period, I was interested in the topic, and I was in incidental contact with pro-Israel and Jewish cultural groups on (an American) campus. I recall that e-mail traffic with such groups and with my Jewish relatives about these alarming events was filled with vague references to the "ghosts of Europe's past," a "resurgence" of a European attitude thought to have been snuffed out, etc. Everyone's unspoken assumption, for some reason, was that the violence was the doing of skinhead-type groups, and there was nothing in even the (purportedly Islamophobe and Judeophile) American press I saw for quite some time that suggested any other conclusion. All the while, one could tune in to the news after 9/11 or the terrorist attacks that followed in Europe and hear talking heads warning in dire tones about the anti-Muslim backlash that was sure to follow.

European authorities eventually revealed that practically all the anti-Semitic attacks were carried out by male youths of "immigrant" communities - although even this was a bit of a euphemism, since it was obviously Muslims rather than Armenian Christians or Vietnamese who were responsible, and many of them were likely second-generation. The French press, as Bawer notes, took to describing many of these blatant assaults as part of a "confrontation between communities," as if the whole business were just an echo of the cycle of provocation and reprisal going on across the Mediterranean. But this was nonsense. There was virtually no evidence supporting either the idea that a white neofascist campaign was occurring or that Jews and Muslims were "clashing" in the streets like Jets and Sharks. "The plain fact," writes Bawer, "is that Muslim adults in Europe do routinely harass Jewish children, while Jewish and Christian adults in Europe virtually never behave in this manner toward children of other faiths." It was years before European authorities released their report, "Manifestations of AntiSemitism in the European Union," commissioned by a Vienna-based EU body called the European Monitoring Center on Racism and Xenophobia (EUMC) and prepared by Berlin's Center for Research on Anti-Semitism (CRA). When the report made it clear who had been responsible for the attacks, the EUMC suppressed it. The information only came out after its contents were leaked onto the internet and even after the leak forced publicity upon the EU, the EUMC's accompanying press release still attributed the violence to white neofascist groups - in other words, precisely the opposite of what the data showed (Bawer 2006, pp. 141-144, 150).

Even if it could not be said aloud that the miniscule number of Jews left in Europe provoked this series of attacks against them outright, the problem was still often talked about as if wholly explicable by Israel's synchronous suppression of Palestinian militants. ${ }^{11}$ Again, this is a dangerous attitude, an evasion of harsh

\footnotetext{
${ }^{11}$ Cf. Cesari's apologetic (2004), which hides Islamic responsibility for the anti-Jewish spike in a footnote and describes it "largely as a response to the Israeli-Palestinian conflict" (pp. 29, 223). She also blames the attraction of young Western Muslims to Al Qaeda-brand jihad on "the experience of daily personal degradation," "a feeling of being illegitimate or unrecognized," "personal humiliation added to a feeling of collective humiliation" (p. 104). Such angry young men are merely "react[ing] to the identity that has been imposed on Muslims" with "the analogue of Western orientalist essentializing" (p. 108). (http://news.bbc. co.uk/2/hi/uk_news/england/west_midlands/6936681.stm)
} 
realities. Islamist rhetoric about Palestinian self-determination, much of it delivered in tiers-mondiste accents of "liberation" or the like, has no logical relationship whatever with an attitude toward Jews in general: ${ }^{12}$ It should have certainly had no ramifications in Europe, where the idea that a Jewish pro-Israel lobby wields backroom political influence is laughable. The absurdity of seeing the post-2000 pogrom as a case of geopolitical outrage holds especially in a state like France, staunchly Arabophile since the 1967 war. If "conflict between communities" is being foisted upon European Muslims by cases of foreign oppression, then why has there been no similar record of anti-Slavic violence following Kosovo and Chechnya or anti-Hindu violence linked to the ongoing struggle over Kashmir?

I suggested above that European Jews (we might add homosexuals) are the canary in the mineshaft. The covering up of the problem, the tendency to euphemize it or explain it away as a reaction to Western geopolitical misdeeds, is part of a broader picture. Liberal democracy risks being crippled by a guilt-induced inability to call vile behaviors on the part of a supposedly oppressed (though certainly far from cowed, for all that) minority groups what they are. "We Europeans have been raised to detest ourselves, certain that, within our world, there is a certain essential evil that must be relentlessly atoned for," declared Pascal Bruckner two decades ago. At the same time, "Islam's nature was judged on its hostility to us and was welcomed for it, as if the criteria for a movement's authenticity consisted of its being anti-Europe" (Bruckner 1986, pp. 4, 33). That sounds grandiose, but some sort of perverse political psychology, over and above ordinary pusillanimity in the face of violent intimidation, must be held accountable for the surrender of liberal values in the face of radical Islam.

As might have been expected, the search to reclaim wounded communal "respect" has bled into a quest for total communal control, sometimes stretching well beyond one's own community. Egalitarian state protection is effectively denied those unfortunate enough to be born into, or imported into, or who even unsuspectingly wander into, many Muslim communities in Europe. Walter Laqueur writes:

Reports from Kreuzberg, Wedding, and other quarters convey interesting examples of how this social pressure manifests itself: Young men stop people in the streets and tell them that if they are not Muslims they should leave the neighborhood. German children have been driven out of local playgrounds. In school there has been pressure on non-Muslims during Ramadan to fast; nonMuslim girls have been pressured to wear clothes similar to those of the Muslim girls or, at least, not indecent skirts or trousers or T-shirts. Parents of schoolchildren have been told that whatever instructions the school may give them, the mosque and its classes always have priority (Laqueur 2007, p. 67).

In 2008, The Archbishop of Canterbury caused a stir in Britain when he suggested that "plural jurisdiction," a fancy way of saying Sharia law, was inevitable for UK

\footnotetext{
${ }^{12}$ And probably little actual relationship to the Islamist worldview. Although street-level protesters who don the Hamas mask and carry "Death to the Jews!" or "Star of David = Swastika" placards may indeed sympathize with the plight of the Palestinians, there is no reason to think that Islamism at its intellectual base cares about Palestinian self-determination, any more than it does Jordanian or Kuwaiti selfdetermination. A recreation of the Caliphate would obviously eliminate Palestine just as it would Israel.
} 
Muslims (http://www.archbishopofcanterbury.org/1575). Nobody should have been surprised. Later that year, two Christian clerics were prohibited from handing out religious pamphlets in a "Muslim area" and were accused of a hate crime for doing so by one of the Muslim law enforcement officers hired to establish a better relationship between majority-Islamic neighborhoods and the British state. Around the same time, the Bishop of Rochester, unwisely spurning his boss, spoke out against the "no-go zones" that were many Muslim neighborhoods (http://www. telegraph.co.uk/news/uknews/1574695/Extremism-flourished-as-UK-lost-Christianity. html). He was then denounced as "Islamophobic" even though such zones clearly do exist - indeed, have been publicly agitated for by the same people who then censured the Bishop for pointing them out - and placed under police protection with his family after receiving death threats.

Managers of Western political institutions have long been giving the same impression as the Archbishop of Canterbury. As goes Kreuzberg, so goes the rest of Western Europe, in Bruce Bawer's summary of the situation:

In many places in Europe, agitation for the transfer of sovereignty has already begun. In France, a public official met with an imam at the edge of Roubaix's Muslim district out of respect for his declaration of the neighborhood as Islamic territory to which she had no right of access. In Britain, imams have pressed the government to officially designate certain areas of Bradford as being under Muslim, not British, law. In Denmark, Muslim leaders have sought the same kind of control over parts of Copenhagen. And in Belgium, Muslims living in the Brussels neighborhood of Sint-Jans-Molenbeek already view it not as part of Belgium but as an area under Islamic jurisdiction in which Belgians are not welcome (Bawer 2006, p. 33).

And again, the most noxious location of such communitarian gangsterism may be the school. The public school is more and more in danger of becoming defunct, in any Western society with vigorous pro-theocratic parties, as a facilitator of a free national culture or a provider of exit options from local or household norms. It is bad enough that Muslim children have been routinely shipped off to foreign madrassas that function, in effect, as Qur'anic memorization academies-cum-Islamist brainwashing centers. But radicalization within Europe is gradually eliminating the necessity for such international dragooning.

In schools where some Muslim girls wore the hijab and others did not, the unveiled girls often bore the verbal insults and threats of Muslim boys. These fundamentalist boys called the unveiled girls 'whores' and in some cases physically attacked the girls. Some Muslim parents had transferred their daughters to private Catholic schools in order to escape the pressure from fundamentalists. Then the situation worsened. Because denouncing other Muslims is sometimes seen as a treasonous act within communities, girls who had had their arms broken or suffered from other forms of attack, lied to their parents and school authorities to protect the perpetrators. The Presidential Commission realized that by allowing individual school principals to determine whether the hijab should be banned, this would enable radical fundamentalists to target and intimidate those principals who enforced the ban (Shore 2006, p. 79). 
In March of 2005, Jean-Pierre Obin of the French Ministry of Education released a report (which like the anti-Semitism report was not officially released but was leaked over the internet) summarizing a study of 61 predominately Muslim schools. He revealed that Muslim students were en masse refusing to do things like sing, dance, play sports, draw a face, or play an instrument. One refused to draw a right angle in math class because of its resemblance to the Christian cross; others refused to swim for fear of pollution by "infidel" water; some refused to read Voltaire, Rousseau, Cyrano de Bergerac, Madame Bovary, or Chrétien de Troyes on grounds of their impiety or their symbolizing Western cultural imperialism. Many would not accept basic facts about Christian and Jewish history and sought, for example, to deny the existence of any pre-Islamic civilization in Egypt. In one school, Muslim pupils had enforced bathroom segregation: one toilet for French children, one for Muslims. A local Muslim leader had persuaded another school to institute apartheid in its gym dressing rooms because "the circumcised should not have to undress alongside the impure" (Bawer 2006, p. 209). ${ }^{13}$

It did not stop with curricular bowdlerization: by the 2000s, portions of the Western European elite had evidently decided that their cultural sphere should basically be subjected to an Islamic line-item veto tout court. Demands from Italian Muslims to remove Dante's Divine Comedy from the schools because of its consigning of Muhammad to hell no longer sounded far-fetched. In 2000, a Dutch opera company cancelled Aisha and the Women of Medina by the Algerian author Assia Djebar after promises that it would create a new Rushdie affair. Performances of Voltaire's plays were successfully suppressed in both Switzerland and France. A celebrated London production of Marlowe's Tamburlaine cut out a scene where the Qur'an is burned, without even facing prior pressure (Jenkins 2007, pp. 239-240). Some alterations would sound fairly ridiculous had not theorists of multiculturalism spilled so much ink on things like them: our poor porcine friends, for example. The UK has banned piggybanks as promotional gifts from banks, while governmental social welfare agencies voluntarily proscribed all pig paraphernalia (calendars, toys, etc.) from their offices (http://www.timesonline.co.uk/tol/news/world/europe/article3419706.ece). Some British classrooms will no longer have the option of screening the talking-pig film Babe or introducing children to a story called "The Three Little Pigs" (http:// news.bbc.co.uk/1/hi/education/7204635.stm). Fortis Bank in The Netherlands, which, for several years, boasted Knorbert the pig as its mascot, recently gave him the boot: According to a bank spokesperson, "Knorbert does not meet the requirements that the multicultural society imposes on us" (http:/www.timesonline.co.uk/tol/news/world/ europe/article3419706.ece). One notes the language, the assumption of a total lack of Western agency in these matters. Many undoubtedly felt that this all was too unimportant to risk expensive litigation, or perhaps worse, over. I recommend viewing it in the opposite way. If the day comes when we no longer have the energy to protect Wilbur or Porky, does anyone really think we will then be fighting for more basic freedoms?

\footnotetext{
${ }^{13}$ Bawer reports that Erna Solberg, Norway's former minister for integration affairs, said that "dumping" of Muslim children into foreign mosques for their education has positive aspects, providing them "knowledge of their own roots, family, culture, and language, the confidence of knowing 'who one is' and strengthened self-image" (p. 59). See also the hair-raising report assembled by Brenner (2002).
} 
As a reprise of the Rushdie Affair, the most recent notable furor over discussion of Muslim stories and institutions has been telling. In response to Muslim furor over the Danish Muhammad cartoons Javier Solana, former Secretary General of NATO and then of the EU, told the aggrieved community, "you can be sure that we will do our utmost to prevent such a thing from happening again," while Franco Frattini, the EU's commissioner for Justice, Freedom and Security, proposed that European media submit to a voluntary code of conduct: "the press will give the Muslim world the message: we are aware of the consequences of exercising the right of free expression, we can and we are ready to self-regulate that right." The former editorin-chief of Denmark's newspaper Politiken argued that his country's major publications should pool together a collection to fund a mosque in Copenhagen, in atonement for the Danes' poor treatment of Muslims. But many of the Muslim protestors who made themselves visible in the aftermath of the cartoons hardly seemed concerned with respect in that sense: Placards at a representative British gathering read, "Behead those who insult Islam" and "Europe you will pay-your 9/ 11 is on its way." A Danish politician who dared to publicly aver that the "blood money" method of settling inter-Islamic disputes should not apply in Denmark had already seen his car and house firebombed; Holland was perhaps even worse hit, with the flight of several insufficiently sensitive government figures into police protection and hiding during the Theo van Gogh affair. After the controversy over Submission, a film about the subjugation of women in Islam co-produced by the murdered van Gogh and the death-sentenced and exiled Ayaan Hirsi Ali, justice minister Piet Donner proposed reviving and enforcing an anti-blasphemy law from 1932. Minister of Economic Affairs Laurens-Jan Brinkhorst responded by saying that the pair "should not have made Submission," echoing the gist of much mainstream left-liberal opinion in Western Europe (Timothy Garton Ash; Tony Judt; The Guardian, which savaged van Gogh and Hirsi Ali's "magnificent disregard for the feelings they might be offending"): that is, the main problem about someone like Hirsi Ali was not her being forced to live in fear but rather her throwing rocks at the hornet's nest. Italy, too, has resurrected a law from the fascist era that prohibits the defaming of religion. In the mid-2000s, the British government stood a single parliamentary vote away from passage of a "Racial and Religious Hatred Bill" that would have make it a criminal offense to incite "religious hatred through threatening words, actions and insults" and that could have been used to freeze out virtually any public-sphere reference to Islam deemed offensive by its dedicatedly sensitive community spokesmen (Jenkins 2007, pp. 238-244; Bawer 2006, pp. 195, 211, 214-215). The UK, indeed, like Canada and much of Western Europe, with a much weaker judicial ideology of protecting freedom of speech at all costs than the USA, has served as a favored node for what has become known as "libel tourism": Publications that seek to illuminate the international funding apparatus for jihadist terrorism or sometimes that simply discuss Islam in too unfavorable a light are taken to court for libel or defamation, particularly in jurisdictions where such concepts are loosely defined (http:/www.iht.com/articles/2008/01/20/business/libel21.php). Even so, the intent is rarely, if ever, to win, but instead to chill speech by financially draining and thus intimidating and demoralizing authors and publishers.

Perhaps the most frightening lesson of the aftermath of the cartoon affair is how easy it may become in the future for the cultural jihadists to achieve their goals 
without resorting to violence at all (though while always implying, of course, that it may follow if and when people cannot bear the anger anymore). We have heard commentary after commentary about how modern terrorists take advantage of globalization - cell phones, websites, international banking, etc. - but one of the less talked about interfaces between globalization and the imposition of theocracy is a more ostensibly legalistic one. International agencies like the UN have become clearinghouses for Muslim complaints about free speech even when occurring far outside a state's own borders. In 2008, a delegation from the Pakistani government warned the EU that unless it placed internal restrictions on free speech as it regards Islam, terrorist attacks on European assets abroad could follow-the Danish embassy in Islamabad was bombed in the same year (http://www.dailytimes.com. pk/default.asp?page $=2008 \% 5$ C06\%5C08\%5Cstory_8-6-2008_pg7_14). Most strangely, but perhaps also most potentially chilling: The aftermath of the cartoon affair led a Jordanian court to summon 12 European citizens-among them numerous newspaper editors but also one Dutch politician, Geert Wilders, like Theo van Gogh the producer of a controversial film - to stand trial in Jordan, in response to claims made by a group called "Messengers of Allah Unite Us," who profess to offer a more "civilized response" to the intolerable images (http://www.cphpost.dk/ get/107525.html). This is a sort of black mass (in)version of the growing trend of international tribunals to cordon off convicted dictators like Augusto Pinochet by telling them where they had better not travel. Most astounding here is what it reveals about the complete brazenness with which even a small, non-oil-producing state like Jordan now knows it can treat Europe - and surely enough, no retaliatory action was taken. The indicted citizens will not literally be given up, of course, but the "Messengers of Allah" find other ways. One is an attempted boycott against all Danish and Dutch imports, unless the companies in question renounce the publication of the cartoons and/or Wilders' film in both the Jordanian and Dutch or Danish press. Several companies have complied. In March of 2008, the 57 states making up the Organization of Islamic Conference successfully forced the UN Human Rights Council to amend a resolution on freedom of expression so that it characterized any criticism of Islam as an act of abuse and religious discrimination (http://www2.ohchr.org/english/bodies/hrcouncil/docs/7session/A-HRC-7-L11Add1.doc). Two publications, Macleans and The Western Standard, and one author, Mark Steyn [America Alone (2006)] were finally the first North Americans taken to court (by Canada's Human Rights Commission in 2007-2008) for that new vintage crime, "Islamophobia" (http://www.nationalpost.com/opinion/columnists/story.html? $\mathrm{id}=5 \mathrm{~b} 471 \mathrm{cb} 6-2 \mathrm{~b} 5 \mathrm{~d}-44 \mathrm{e} 0-\mathrm{b} 5 \mathrm{e} 0-973 \mathrm{fda} 2 \mathrm{ca} 5 \mathrm{dd} \& \mathrm{p}=1$ ). Orwellian language-flipping came to a weird pass over the British television program "Undercover Mosque," which showed footage of radical Imams in the UK spewing hatred against Christians and Jews, advocating the beating of women and praising Osama Bin Laden; "Islamophobia" was the magic word again as local police chose, instead of investigating the mosque, to charge the network that aired the documentary itself under the Public Order Act of 1986: "inflammatory material likely to stir racial hatred" (http://news.bbc.co.uk/2/hi/uk_news/england/west_midlands/6936681.stm).

This cringing deference to the professed cultural sensitivities of others (though again, since no other post-immigrant group makes anything remotely like these claims we should be wary of seeing them as "cultural" as opposed to theocratic) does 
not evince much fondness for its own. One could say that its embrace of tribalism is rather unegalitarian. We have already seen that Jewish pride, or even self-defense, will hold little water. But in some cases, things have gone even further, and the results might be comical if bloodier incidents do not make it clear how far, and fast, societies can slip down the slope. A homosexual who escapes, say, Mississippi for Amsterdam, may eventually come to wish s/he had stayed home, as Muslim gaybashing in European cities has risen to alarming levels. In May 2002, a gay German couple attending, of all things, a multicultural street festival, was beaten by a gang of immigrant youths who shouted "Gay pigs! You should all be gassed!" After a similar antigay incident in Holland, a spokesperson for Human Rights Watch had this to say: "There's still an extraordinary degree of racism in Dutch society. Gays often become the victims of this when immigrants retaliate for the inequities that they have to suffer." So many groups to liberate, so limited a cache of outrage: elsewhere, in this so-called black-red alliance, the Socialist Workers' Party leaders enforced gender segregation at a rally in Trafalgar Square and ordered non-Muslim women to cover their heads when demonstrating outside the Israeli embassy in London. In 2004, Mona Sahlin, then Sweden's Minister for Integration, appeared at a Kurdish mosque wearing a head covering and told her Muslim audience that Swedes were in fact jealous of them because they had a rich and unifying culture and Sweden had mere silly things like Midsummer's Night. Christian students have also reported being picked on by Muslims and being effectively told by authorities not to wear crosses to school. And this cultural démarche has hit the most neutralitytending of nations: schoolboys in The Netherlands were ordered to remove Dutchflag patches from their backpacks because they were too "provocative," while two Swedish girls were sent home for donning sweaters with small likenesses of their country's flag (Bawer 2006, pp. 39, 57, 101, 146-147, 214-218).

\section{Conclusion}

The academy has tended to seriously misunderstand the ongoing European kulturkampf as a byproduct of the sociological variables it is comfortable with: chiefly economic deprivation and/or white racism. While these two elements are certainly present - as they are with disadvantaged minorities anywhere - they do not adequately explain the dangerously illiberal movements brewing among European Muslims, nor address the disconcertingly tepid European response.

Attentiveness to socioeconomic context should not blind us to ideological factors that break such familiar bonds. It will ultimately do no favors to toleranceand least of all to those purportedly offered toleration by a steadfast refusal to name or combat radical Islamism - if an ideologically unified West neglects its duty to stand and fight.

Open Access This article is distributed under the terms of the Creative Commons Attribution Noncommercial License which permits any noncommercial use, distribution, and reproduction in any medium, provided the original author(s) and source are credited. 


\section{References}

Barry, Brian. Culture and Equality: An Egalitarian Critique of Multiculturalism (Harvard University Press, 2002), p. 129

Bawer Bruce (2006) While Europe Slept: How Radical Islam is Destroying the West From Within. Doubleday, New York, p 166

Bellil Samira (2002) Dans l'enfer des tournantes. Denoël, Paris

Berman Paul (2003) Terror and Liberalism. Norton, New York

Brenner Emmanuel (2002) Les territoires perdues de la république: antisémitisme, racisme et sexisme en milieu scolaire. Mille et une nuits, Paris

Bruckner Pascal (1983) Le sanglot de l'homme blanc: Tiers-monde, culpabilité, haine de soi. Editions du Seuil, Paris

Bruckner, Pascal. The Tears of the White Man: Compassion as Contempt, trans. William R. Beer (New York: The Free Press, 1986)

Bruckner Pascal (2006) La tyrannie de la penitence: Essai sur le masochisme occidental. Grasset, Paris

Buruma Ian, Margalit Avishai (2004) Occidentalism: The West in the Eyes of its Enemies. Penguin, New York

Cesari Jocelyn (2004) When Islam and Democracy Meet: Muslims in Europe and in the United States. Macmillan, New York

Ferguson, Niall. “A World Without Power,” Foreign Policy, July/August 2004

Hitchens, Christopher. “Against Rationalization," The Nation, October 8, 2001

Huntington Samuel P (1996) The Clash of Civilizations and the Remaking of World Order. Simon \& Schuster, New York, p 209

Jenkins, Philip. God's Continent: Christianity, Islam, and Europe's Religious Crisis (Oxford: Oxford University Press, 2007), pp. 186-187

Karsh, Efraim. Islamic Imperialism: A History (New Haven, CT: Yale University Press, 2006)

Kepel, Gilles. Jihad: The Trail of Political Islam, trans. Anthony F. Roberts (Cambridge, MA: Belknap, 2002), p. 47

Khomeini, Ruhollah. Islam and Revolution: Writings and Declarations, trans. Hamid Algar (London: KPI, 1985)

Klausen, Jytte. The Islamic Challenge: Politics and Religion in Western Europe (Oxford: Oxford University Press, 2005)

Laqueur Walter (2007) The Last Days of Europe: Epitaph for an Old Continent. Thomas Dunne Books, New York

Lewis, Bernard. Islam and the West (Oxford: Oxford University Press, 1993), p. 13

Maududi, Maulana. Selected Writings and Speeches, 2 vols., trans. S. Zakir Aijaz (Karachi: International Islamic Publishers, 1981), vol. I, p. 85

Pryce-Jones David (2006) Betrayal: France, the Arabs, and the Jews. Encounter, New York, pp 11-14

Qutb Sayyid (1967) This Religion of Islam. International Islamic Publishing House, Riyadh, p 10

Qutb Sayyid (1977) Islam and Universal Peace. American Trust Publications, Indianapolis, p 3

Qutb Sayyid (1980) Milestones. Unity, Cedar Rapids, IA, p 12

Qutb, Sayyid. Basic Principles of the Islamic Worldview, trans. Rami David (North Haledon, NJ: Islamic Publications International, 2006), p. 2

Ruthven, Malise. A Fury For God: The Islamist Attack on America (London and New York: Granta, 2002), pp. 68-69

Shari'ati, Ali. Marxism and Other Western Fallacies: An Islamic Critique, trans. R. Campbell (Berkeley: Mizan Press, 1980), p. 39

Shore, Zachary. Breeding Bin Ladens: America, Islam, and the Future of Europe (Baltimore, MD: Johns Hopkins University Press, 2006)

Taguieff, Pierre-André. Rising From the Muck: The New Anti-Semitism in Europe, trans. Patrick Camiller (Chicago: Ivan R. Dee, 2004), p. 52

Wikan, Unni. Generous Betrayal: Politics of Culture in the New Europe (Chicago, IL: University of Chicago Press, 2002), p. 53

Wiktorowicz Quintan (2005) Radical Islam Rising: Muslim Extremism in the West. Rowan and Littlefield, Lanham, MD 